\title{
Iron overload in beta thalassemia major patients
}

\author{
Atthanayaka Mudiyanselage Dilhara Sewwandi Karunaratna, \\ JG Shirani Ranasingha, Rasnayaka Mudiyanselage Mudiyanse
}

\begin{abstract}
Aims: Beta thalassemia is the most common monogenic hereditary hemoglobin disorder, which poses a major health burden to SriLanka. Regular transfusions of erythrocytes required for survival of these patients lead to inevitable iron overload, which is manifested, by elevated serum ferritin levels. Progressive deposition of iron leads to dysfunction and failure of the major organs. The aim of this study was to evaluate the iron overload of the beta thalassemia major patients in one of the thalassemia centres in Sri Lanka and to find its effect on growth status of the patients. Methods: The study included forty patients with confirmed diagnosis of beta thalassemia major, undergoing any chelation treatment. The mean age of the study group was $10.97 \pm 5.9$ years with a range of $2-20$ years. The patients were interviewed for the socio-demographic variables and their medical histories were obtained from the hospital files. Serum ferritin concentration, height and weight of the patients
\end{abstract}

Atthanayaka Mudiyanselage Dilhara Sewwandi Karunaratna ${ }^{1}$, JG Shirani Ranasingha ${ }^{2}$, Rasnayaka Mudiyanselage Mudiyanse $^{3}$

Affiliations: ${ }^{1} B V S c$, Postgraduate Institute of Science, University of Peradeniya, Peradeniya, Sri Lanka; ${ }^{2} \mathrm{PhD}$, Professor, Postgraduate Institute of Science, University of Peradeniya, Peradeniya, Sri Lanka; ${ }^{3} \mathrm{MD}$, Professor in Pediatrics, Department of Pediatrics, Faculty of Medicine, University of Peradeniya, Peradeniya, Sri Lanka.

Corresponding Author: JG Shirani Ranasingha, Head of Department, Department of Biochemistry, Faculty of Medicine, University of Peradeniya, Peradeniya, Sri Lanka, KY20400; Email: shirani05@pdn.ac.lk.

Received: 05 December 2016

Accepted: 19 January 2017

Published: 12 August 2017 were measured and body mass index (BMI) was calculated. Results: The mean serum ferritin concentration was $2992.2 \pm 1575.35 \mathrm{ng} / \mathrm{ml}$ which showed a significant correlation with age and duration of blood transfusion. The mean z-score for height was $-2.3 \pm 1.06$ and $50 \%$ of the patients were stunted. The mean z-score for BMI was $-1.32 \pm 1.28$ and $35 \%$ of the patients were wasted. Both height and BMI had no significant correlation with iron overload of the patients. Conclusion: Iron overload and growth retardation were common in beta thalassemia major patients of the treatment center evaluated in this study in Sri Lanka. However, there was no significant relationship between physical growth and iron overload.

Keywords: Beta thalassemia major, Growth status, Iron overload

\section{How to cite this article}

Karunaratna AMDS, Ranasingha JGS, Mudiyanse RM. Iron overload in beta thalassemia major patients. Int $\mathrm{J}$ Blood Transfus Immunohematol 2017;7:33-40.

Article ID: 100032IJBTIAK2017

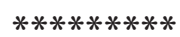

doi:10.5348/ijbti-2017-32-OA-5

\section{INTRODUCTION}

Beta thalassemia is the most common monogenic hereditary hemoglobin disorder, which poses a major health burden in Sri Lanka. The national incidence of 6080 cases per year together with the estimated life span 
of 20-25 years has resulted in a patient load exceeding 1500 patients. The highest prevalence of beta thalassemia major disease is seen in three provinces namely Wayamba, North Central and Uva. However, cases are found all over the country. The prevalence of beta thalassemia trait among Sri Lankan population varies from 1-5\% [1, 2].

The patients with beta thalassemia major suffer from chronic anemia due to hemolysis and ineffective erythropoiesis. Therefore, regular blood (erythrocytes) transfusions to maintain the pre transfusion hemoglobin concentration between 9.5 and $10.5 \mathrm{~g} / \mathrm{dL}$ is essential for their survival and avoidance of complications. But, frequent transfusions result in inevitable accumulation of iron. Patients may accumulate $5 \mathrm{~g}$ of iron per year following transfusion of 25 units of blood per year. Increased gastrointestinal iron absorption due to increased hepcidin in thalassemia patients, cause further accumulation of iron. As a consequence of progressive iron overload, the iron binding protein; transferrin exceeds its capacity to bind with circulating free iron, releasing non transferrin bound iron into the blood circulation. The non-transferrin bound iron is unstable and exchange from ferric to ferrous status generating reactive oxygen species (ROS). Accumulation of free radicals, due to iron overload leads to lipid peroxidation and generation of both saturated and unsaturated aldehydes, causing cell damage $[10,11]$. Progressive deposition of iron leads to dysfunction and failure of the major organs including heart, liver and endocrine glands such as pituitary, thyroid, parathyroid, adrenal and endocrine pancreas. Therefore, proper iron chelation therapy is mandatory for transfused patients with beta thalassemia major [3-11].

Patients with poor compliance to chelation therapy develop complications of iron overload including cardiac failure [12], cirrhosis [13], growth retardation [14], delay in sexual maturation [14], diabetes mellitus [15], hypothyroidism, hypoparathyroidism and osteopenia [15]. However lifelong administration of iron chelation regimens has posed challenges to clinicians and patients equally [16]. Poor compliance to chelation therapy and severe iron overload among patients has been reported in both developed and developing countries including United States [17], Pakistan [18], Egypt [19], India [20], Japan [21], Italy [22] and Dubai [23].

Therefore, regular assessment of iron status is essential for the efficient management of iron overload of beta thalassemia major patients. Serum ferritin level correlates with the iron burden in the body [24]. Serial measurements of serum ferritin level are widely used worldwide as an easy and reliable method of assessing the iron status in patients.

As a consequence of disturbed iron metabolism, growth failure is common among children and adolescents in multi-transfused beta thalassemia major patients which is due to many factors such as chronic anemia, iron over load, deficiency of growth hormone and thyroid hormone, chelation therapy and zinc deficiency.
Previous studies have shown a significant relationship between high serum ferritin level and growth failure of the beta thalassemia major patients $[25,26]$.

The aim of this study is to evaluate the iron overload and growth status of the beta thalassemia patients in one of the thalassemia centres in Sri Lanka and to find out the relationship between them.

\section{MATERIALS AND METHODS}

\section{Study Design}

This was a cross sectional study conducted on iron overload of the transfusion dependent beta thalassemia major patients at Paediatric Unit, Peradeniya Teaching Hospital in Sri Lanka during the period, o1 January 2014 to 31 December 2014.

\section{Subjects}

The study population consisted of 40 children of both genders with confirmed diagnosis of beta thalassemia major under any chelation regimen. All the patients are in the age group between 2 and 20 years. The diagnosis of beta thalassemia major was confirmed either by hemoglobin electrophoresis profiles or HPLC. Exclusion criteria included abnormal liver or renal functions, presence of acute infections at the time of blood collection. This study was approved by Ethical Review Committee, Faculty of Medicine, University of Peradeniya (2013/EC/43). The written consents were obtained from all the guardians of patients allowing their children to participate in the study.

\section{Methodology}

A standardized and validated questionnaire was used by the interviewer to gather information from all the patients during their hospital stay for regular blood transfusion. The questionnaire was pre tested with some patients in the pediatric unit of Peradeniya teaching hospital to ensure its feasibility and accuracy.

\section{Assessment of mean pretransfusion hemoglobin level}

The pretransfusion hemoglobin level which was measured by Drabskin method was taken from the past medical records of the patients. The pretransfusion levels over one year period were traced and the average was considered as the mean pretransfusion hemoglobin level.

\section{Assessment of delayed puberty}

Delayed puberty was diagnosed in boys and girls by absence of testicular development by age of 14 years and the absence of breast development by the age of 13 years respectively $[27,28]$. 


\section{Measurement of anthropometric param- eters}

Height of each patient was measured using a standard stadiometer. Weight was measured with light clothes using a standardized digital bathroom body weight scale. The $\mathrm{z}$-scores for height and BMI were calculated by standard equations provided by World Health Organization [29].

$$
\begin{gathered}
\text { Z-score }(\text { height })=\frac{(\text { Observed value })-(\text { Median reference value })}{Z \text {-score value for reference population }} \\
\text { Z-score }(\text { BMI })=\frac{(\text { Observed value } \div \mathrm{M})^{\mathrm{L}}-1}{\mathrm{~L} \times \mathrm{S}}
\end{gathered}
$$

In this formula $\mathrm{L}, \mathrm{M}$ and $\mathrm{S}$ values are for the reference population. $\mathrm{M}$ is the reference median value which estimates the population mean. $\mathrm{L}$ is the power needed to transform the data in order to remove skewness (i.e., to normalize the data). $\mathrm{S}$ is the coefficient of variation (or equivalent).The reference values for z-score for height and BMI were taken from the WHO standards [29].

\section{Analysis of serum ferritin level}

Blood samples $(5 \mathrm{ml})$ were collected and centrifuged to separate serum. The serum was stored in $-60^{\circ} \mathrm{C}$ until analysis. Serum ferritin level was analysed by enzyme linked immunosorbent assay (ELISA) kit (Fortress Diagnostics, Antrim, United Kingdom). The lower cut point for serum ferritin concentration for children is taken as $12 \mathrm{ng} / \mathrm{dl}$ [30].

\section{Statistical analysis}

The data was analysed by SPSS 16.0 statistical software (Softonic, Barcelona, Spain). The subjects were categorized into two groups based on their mean serum ferritin levels which are less than $3000 \mathrm{ng} / \mathrm{ml}$ and more than or equivalent to $3000 \mathrm{ng} / \mathrm{ml}$. Student $t$-test was used to compare the groups. Correlations between iron overload and growth parameters were assessed using the Pearson correlation test. The p-values of less than 0.05 were considered statistically significant.

\section{RESULTS}

This study included 40 patients suffering from beta thalassemia major, with 22 (55\%) females and 18 (45\%) males. The mean age was $10.97 \pm 5.9$ years with a range of 2-20 years. The duration of blood transfusion ranged from 14-235 months with a mean of $125.82 \pm 70.53$. The median age at the first transfusion was six months (range 2-18 months) and the mean transfusion requirement was $265.01 \mathrm{ml} / \mathrm{kg}$ every year (range $379.1-500.0 \mathrm{ml} / \mathrm{kg} /$ year). The mean pretransfusion hemoglobin concentration was $8.15 \pm 1.21 \mathrm{~g} / \mathrm{dl}$ with a range of $4.00-10.3 \mathrm{~g} / \mathrm{dl}$ and 37 patients (92.5\%) were below the expected minimum hemoglobin concentration $(9.5 \mathrm{~g} / \mathrm{dl})$. During the time of this study, all the patients were under deferasirox therapy and before 2010 they were on deferoxamine and deferiprone therapy. The current mean dose of deferasirox iron chelation therapy was $22.5 \pm 4.5 \mathrm{mg} / \mathrm{kg} /$ day.

The mean serum ferritin concentration was 2992.2 $\pm 1575.35 \mathrm{ng} / \mathrm{ml}$ (range $875.5-7625 \mathrm{ng} / \mathrm{ml}$ ). The ferritin concentration was less than $1500 \mathrm{ng} / \mathrm{ml}$ in six patients $(15 \%)$ and 20 patients (50\%) were with serum ferritin levels between 2500-5000 $\mathrm{ng} / \mathrm{ml}$. Majority of the patients with high serum ferritin concentration $(>2500 \mathrm{ng} / \mathrm{ml}$ ) were aged more than 10 years. Mean serum ferritin concentration of the females patients was $3057.54 \pm 1474.05$ while in male patients it was 2924.55 \pm 1592.76 . There was no significant difference of mean serum ferritin concentration between two groups $(\mathrm{p}=0.78)$.

There was a significant relationship between iron overload with the age and the duration of blood transfusion of the patients $(<0.05)$. Blood transfusion volume $(\mathrm{ml} / / \mathrm{kg} /$ year$)$, mean pretransfusion hemoglobin concentration and method of chelation showed no relationship with mean serum ferritin concentration (>0.05) (Table 1).

The most common endocrine complication among the older patients ( $>12$ years old) in the study group was delayed puberty $(\mathrm{n}=10,66.7 \%)$ (Younger patients $<12$ years were not considered when calculating the prevalence). Moreover, in this study, it was found that the mean z-score for height is $-2.3 \pm 1.06$ (range -0.75 to -5.06 ). Out of 40 patients, $20(50 \%)$ were stunted (z-score for height $<-2$ $\mathrm{SD})$ and 10 (25\%) of them were severely stunted (z-score for height <-3 SD). Only 20 (50\%) patients were of normal height (z-score for height $\ddot{y}$-2SD) (Table 2).

The mean z-score for BMI is $-1.32 \pm 1.28$ (range 0.88 to -3.82). Out of 40 thalassemia patients, $35 \%$ (14) were wasted (z-score for BMI <-2SD) and 7.5\% (3) of them were severely wasted (z-score for $\mathrm{BMI}<-3 \mathrm{SD}$ ) and the remaining were normal (z-score for BMI $\ddot{y}-2 S D$ ) (Table 2). There was no significant correlation between mean ferritin concentration and $\mathrm{z}$-scores for height $(\mathrm{p}=0.32, \mathrm{r}$ $=-0.16)$ and BMI $(\mathrm{p}=0.78, \mathrm{r}=0.28)$

In this study, it was found that $57.8 \%$ (11) of children below 10 years old were of normal height and $78.9 \%$ (15) were of normal BMI. Out of the patients above 10 years old, 57\% (12) were stunted and 48\% (9) were wasted (Table 3). There was a significant negative correlation between z-score for height and age of the patients $(\mathrm{p}=$ $0.02, \mathrm{r}=-0.3)$.

\section{DISCUSSION}

Beta thalassemia major is a common hereditary hemoglobinopathy in Sri Lanka. Iron overload and growth retardation are common secondary complications in multi-transfused thalassemia patients. Therefore, effective iron chelation and close monitoring of iron burden is crucial in these patients. The measurement of 
serum ferritin concentration is used in this study to assess the iron status of the patients as it is an easy, cost effective and noninvasive indicator of iron overload.

In our study, iron burden and growth status of 40 beta thalassemia patients were evaluated. Beta thalassemia major patients should maintain their serum ferritin levels below $1500 \mathrm{ng} / \mathrm{ml}$ to minimize the possible complication of iron overload. In this study, only $15 \%$ of patients had values below $1500 \mathrm{ng} / \mathrm{ml}$. It was reported that $12.5 \%$ of beta thalassemia major patients were with serum ferritin levels less than $1000 \mathrm{ng} / \mathrm{ml}$ in a study conducted in Bhopal, India [20]. However, a similar study conducted in Western India reported that only $2 \%$ of the patients were with serum ferritin level less than $1000 \mathrm{ng} / \mathrm{ml}$ [31].

The mean serum ferritin concentration of the patients was $2992.2 \pm 1575.35 \mathrm{ng} / \mathrm{ml}$, which is significantly high when compared with $12-122 \mathrm{ng} / \mathrm{ml}$, the recommended serum ferritin concentration in children [30]. Therefore, proper adherence to iron chelation therapy and close monitoring of iron burden is mandatory. However, a similar study conducted in 2000 in Colombo has reported even high mean serum ferritin level, $5743 \mathrm{ng} / \mathrm{ml}$ in a group of beta thalassemia major patents managed in Lady Ridgeway Hospital [32]. Introduction of deferasirox, a novel iron chelating drug with high compliance might attribute to this marked improvement of management of iron burden in Sri Lankan beta thalassemia patients. Moreover, similar studies carried out in other South Asian countries have reported high mean ferritin levels when compared to values of this study. Mean serum ferritin levels reported to be $4236.5 \mathrm{ng} / \mathrm{ml}, 6723 \mathrm{ng} / \mathrm{ml}$ and $3272.5 \mathrm{ng} / \mathrm{ml}$ in studies conducted in Pakistan [18], India [33] and Saudi Arabia [34] respectively. However, Cunningham et al. reported that serum ferritin level was $1696 \mathrm{ng} / \mathrm{ml}$ and Eghbali et al. reported that mean serum ferritin was $1927 \mathrm{ng} / \mathrm{ml}$ in studies conducted in North America [35] and Iran [36] respectively. These differences in iron overload can be explained by differences in health care standards of those countries and socio-economical background of the patients. The data on comparative serum ferritin levels of thalassemia major patients in different parts of the world is summarized in Table 4 .

Since age and duration of blood transfusion showed a significant relationship with mean serum ferritin concentration, poor adherence to chelation therapy may lead to progressive iron overload in beta thalassemia major patients. Therefore, close monitoring of the iron burden and proper iron chelation therapy will be beneficial in management of beta thalassemia major patients.

As growth failure is a common secondary complication of multi-transfused beta thalassemia major patients who are under iron chelation therapy $[37,38]$, in addition to the iron burden, the growth status of the patients also was evaluated.

According to our study, 50\% of the patients were stunted. Similar findings were reported in a study conducted in Egypt, which specified that $49 \%$ of multitransfused beta thalassemia patients were stunted [37]. Moreover, Hashemi et al. observed 46\% of beta

Table 1: The comparison of clinical variables between two groups (based on serum ferritin concentration) in beta thalassemia major patients

\begin{tabular}{lccc} 
& $\begin{array}{c}\text { Mean Ferritin concentration } \\
<\mathbf{3 0 0 0} \mathbf{~ n g} / \mathbf{m l} \\
\text { Mean (SD) }\end{array}$ & $\begin{array}{c}\text { Mean Ferritin concentration } \\
>=\mathbf{3 0 0 0} \text { ng/ml } \\
\text { Mean (SD) }\end{array}$ & $\begin{array}{c}\text { p-value } \\
\text { (SD) }\end{array}$ \\
Mean age (years) & $9.1 \pm 6.0$ & $13.3 \pm 5.3$ & $0.02^{*}$ \\
Duration of blood transfusion (months) & $103.7 \pm 72.7$ & $152.8 \pm 62.3$ & $0.03^{*}$ \\
Blood transfusion volume (ml/kg/year) & $256.8 \pm 65.8$ & $270.2 \pm 84.3$ & 0.57 \\
Pretransfusion hemoglobin level (g/dl) & $8.1 \pm 1.2$ & $8.2 \pm 1.3$ & 0.92 \\
Deferasirox dose (mg/kg/day) & $60.8 \pm 11.8$ & $62.7 \pm 12.9$ & 0.65 \\
\hline
\end{tabular}

significant at $\mathrm{p}<0.05$, Abbreviations: $\mathrm{SD}=$ Standard deviation

Table 2: Growth parameters and iron overload status in beta thalassemia major patients

\begin{tabular}{|c|c|c|c|c|c|c|}
\hline \multirow{2}{*}{$\begin{array}{l}\text { Serum ferritin } \\
\text { concentration } \\
(\mathrm{ng} / \mathrm{ml})\end{array}$} & \multicolumn{3}{|c|}{ Height for Age } & \multicolumn{3}{|c|}{ Body mass index for Age } \\
\hline & Normal & Mild stunting & $\overline{\text { Severe stunting }}$ & Normal & Mild wasting & $\begin{array}{c}\text { Severe } \\
\text { wasting }\end{array}$ \\
\hline$<1500$ & $4(66.6 \%)$ & $1(16.7 \%)$ & $1(16.7 \%)$ & $4(66.7 \%)$ & $2(33.3 \%)$ & o (o\%) \\
\hline $1500-<2500$ & $5(50 \%)$ & $3(30 \%)$ & $2(20 \%)$ & $4(40 \%)$ & $4(40 \%)$ & $2(20 \%)$ \\
\hline $2500-5000$ & $9(45 \%)$ & $6(30 \%)$ & $5(25 \%)$ & $14(70 \%)$ & $5(25 \%)$ & $1(5 \%)$ \\
\hline$>5000$ & $2(50 \%)$ & $1(25 \%)$ & $1(25 \%)$ & $4(100 \%)$ & o (o\%) & o (o\%) \\
\hline Total & $20(50 \%)$ & $10(25 \%)$ & $10(25 \%)$ & $26(65 \%)$ & $11(27.5 \%)$ & $3(7.5 \%)$ \\
\hline
\end{tabular}


Table 3: Growth parameters in beta thalassemia major patients of different age groups

\begin{tabular}{|c|c|c|c|c|c|c|}
\hline \multirow[b]{2}{*}{ Age (Years) } & \multicolumn{3}{|c|}{ Height for Age } & \multicolumn{3}{|c|}{ Body mass index for Age } \\
\hline & Normal & Mild stunting & $\begin{array}{c}\text { Severe } \\
\text { stunting }\end{array}$ & Normal & Mild wasting & Severe wasting \\
\hline$<5$ & $5(71.4 \%)$ & $1(14.2 \%)$ & $1(14.2 \%)$ & $6(85.7 \%)$ & $1(14.3 \%)$ & o (o\%) \\
\hline $5^{-10}$ & $6(50 \%)$ & $4(33 \cdot 3 \%)$ & $2(16.7 \%)$ & $9(75 \%)$ & $3(25 \%)$ & o (o\%) \\
\hline$>10$ & $9(42.9 \%)$ & $5(23.8 \%)$ & $7(33.3 \%)$ & $11(52.3 \%)$ & $7(33.3 \%)$ & $3(14.2 \%)$ \\
\hline
\end{tabular}

Table 4: Comparative serum ferritin levels

\begin{tabular}{llcc} 
Reference & Country & $\begin{array}{c}\text { Mean serum ferritin } \\
\text { level }\end{array}$ & $\begin{array}{c}\text { \% of patients with serum ferritin level } \\
\text { less than 1000ng/ml }\end{array}$ \\
\hline Shah et al. [31] & Western India & - & $2.00 \%$ \\
Mishra and Tiwaria [20] & Bhopal, India & - & $12.5 \%$ \\
Lucas et al. [32] & Colombo, Sri-Lanka & $5743 \mathrm{ng} / \mathrm{ml}$ & - \\
Choudhry et al. [33] & India & $6723 \mathrm{ng} / \mathrm{ml}$ & - \\
Riaz et al. [18] & Pakistan & $4236.5 \mathrm{ng} / \mathrm{ml}$ & - \\
Cunningham et al. [35] & North America & $1696 \mathrm{ng} / \mathrm{m}$ & - \\
Eghbali et al. [36] & Iran & $1927 \mathrm{ng} / \mathrm{ml}$ & - \\
Al Jaouni et al. [34] & Saudi Arabia & $3272.5 \mathrm{ng} / \mathrm{ml}$ & - \\
\hline
\end{tabular}

thalassemia patients were stunted $(<5$ th percentile) in a study conducted in Iran [25].

The height for age showed a significant negative correlation with the age. This suggests the development of short stature is highly associated with disease progression. Olivieri et al. reported that growth failure is associated with long-term use of deferoxamine therapy [39]. In the current study, all the older patients exceeding 10 years of age were under deferoxamine therapy before 2010 for longer duration when compared with the younger patients. However the association between short stature and long-term previous exposure to deferoxamine therapy cannot be established as several compounding factors like chronic anemia, zinc deficiency, high ferritin levels at their early childhood can affect the growth.

This study did not demonstrate any relationship between serum iron overload and short stature. Our results match with the findings of a study which specifies that there is no association between SD scores of height of the patients and degree of chelation [40]. The short stature among children in our group may be attributed to other contributing factors including genetic makeup, long-term use of iron chelators, chronic anemia and malnutrition due to poor socio-economic status of the patients. In contrast, many studies reported significant relationship between high serum ferritin levels and short stature [25, 26, 37]. However, we have not evaluated children's height in relation to mid parental height.

Delayed puberty is the most common endocrine complication observed among the older patients $(>12$ years old) of this study and short stature is more prevalent among the older patients. Therefore, delayed puberty might be associated with short stature.

In this study, it was revealed that $37 \%$ of the patients were wasted and similar study from Egypt revealed that $30 \%$ of the beta thalassemia major patients had significantly low BMI levels. Further, our results showed that low BMI values of the patients were not associated with either the age of the patients or high serum ferritin levels. Similarly, a study from India revealed that there is no correlation between physical growth and serum ferritin levels [38].

Patients in this study group have records of serum ferritin levels done regularly however lack of standardization prevail us from using such data. For the purpose of this study serum ferritin level was measured only once during the study due to financial constraints. However, single time point values of serum ferritin level may not reflect the status of iron overload accurately in beta thalassemia major patients. Furthermore, this might be the reason to the finding of no significant correlation between the serum ferritin and growth in this study.

Small sample size is another limitation of this study. Moreover, growth status of the age and sex matched healthy individuals was not assessed in this study. Therefore, more extensive multicenter studies with larger sample size are required in this regard.

\section{CONCLUSION}

This study concludes that the iron overload and growth retardation is common among beta thalassemia 
major patients in Sri Lanka. But, there was no significant relationship between physical growth and iron overload in our situation. Therefore, it is important to evaluate the other contributing factors including chronic anemia, long-term use of chelators, genetic and socioeconomic makeup of the study group that may attribute to growth retardation in our patients. Further, proper management of iron overload is crucial to minimize the complications of beta thalassemia major patient and to increase their quality of life.

\section{$* * * * * * * * *$}

\section{Acknowledgements}

We would like to thank Mr. JMNS Nawaratna, Mr. CN Perera and Mrs. PC Rajakaruna for their assistance in sample collection and laboratory analysis. Moreover, our thanks go to director and staff members of the Peradeniya Teaching Hospital.

\section{Author Contributions}

Atthanayaka Mudiyanselage Dilhara Sewwandi Karunaratna - Substantial contributions to conception and design, Acquisition of data, Analysis and interpretation of data, Drafting the article, Final approval of the version to be published

JG Shirani Ranasingha - Substantial contributions to conception and design, Acquisition of data, Analysis and interpretation of data, Revising it critically for important intellectual content, Final approval of the version to be published

Rasnayaka Mudiyanselage Mudiyanse - Substantial contributions to conception and design, Acquisition of data, Analysis and interpretation of data, Revising it critically for important intellectual content, Final approval of the version to be published

\section{Guarantor}

The corresponding author is the guarantor of submission.

\section{Conflict of Interest}

Authors declare no conflict of interest.

\section{Copyright}

(C) 2017 Atthanayaka Mudiyanselage Dilhara Sewwandi Karunaratna et al. This article is distributed under the terms of Creative Commons Attribution License which permits unrestricted use, distribution and reproduction in any medium provided the original author(s) and original publisher are properly credited. Please see the copyright policy on the journal website for more information.

\section{REFERENCES}

1. de Silva S, Fisher CA, Premawardhena A, et al. Thalassaemia in Sri Lanka: Implications for the future health burden of Asian populations. Sri Lanka Thalassaemia Study Group. Lancet 2000 Mar 4;355(9206):786-91.

2. Annual health bulletin. Colombo, Sri Lanka: Ministry of Health; 1996.

3. Schwartz E. Thalassemia syndromes. In: Miller D, Baehner R, editors. Smith's Blood Diseases of Infancy and Childhood. 6ed. St Louis; Mosby; 1989. p. 428.

4. Pootrakul P, Kitcharoen K, Yansukon P, et al. The effect of erythroid hyperplasia on iron balance. Blood 1988 Apr;71(4):1124-9.

5. Old JM, Olivieri NF, Thein SL. Diagnosis and management of thalassaemia. In: Weatherall DJ, Clegg B. editors. The Thalassaemia Syndromes. 4ed. Oxford, England: Blackwell Science; 2001. p. 630-85.

6. Cappellini MD, Cohen A, Eleftheriou A, Piga A, Porter $\mathrm{J}$, Taher A. Guidelines for the clinical management of thalassemia. 2ed. Nicosia, Cyprus: Thalassemia International Federation; 2008.

7. Olivieri NF, Brittenham GM. Iron-chelating therapy and the treatment of thalassemia. Blood 1997 Feb 1;89(3):739-61.

8. Pippard MJ, Callender ST, Warner GT, Weatherall DJ. Iron absorption and loading in beta-thalassaemia intermedia. Lancet 1979 Oct 20;2(8147):819-21.

9. Piomelli S. The management of patients with Cooley's anemia: Transfusions and splenectomy. Semin Hematol 1995 Oct;32(4):262-8.

10. Hershko C, Link G, Cabantchik I. Pathophysiology of iron overload. Ann N Y Acad Sci 1998 Jun 30;850:191201.

11. Andrews NC, Schmidt PJ. Iron homeostasis. Annu Rev Physiol 2007;69:69-85.

12. Modell B, Khan M, Darlison M. Survival in betathalassaemia major in the UK: data from the UK Thalassaemia Register. Lancet 2000 Jun 10;355(9220):2051-2.

13. Restivo Pantalone G, Renda D, Valenza F, et al. Hepatocellular carcinoma in patients with thalassaemia syndromes: Clinical characteristics and outcome in a long term single centre experience. $\mathrm{Br} \mathrm{J}$ Haematol 2010 Jul;150(2):245-7.

14. De Sanctis V, Eleftheriou A, Malaventura C. Prevalence of endocrine complications and short stature in patients with thalassaemia major: A multicenter study by the thalassaemia international federation (TIF). Pediatr Endocrinol Rev 2004 Dec;2 Suppl 2:249-55.

15. Borgna-Pignatti C, Rugolotto S, De Stefano P, et al. Survival and complications in patients with thalassemia major treated with transfusion and deferoxamine. Haematologica 2004 Oct;89(10):118793.

16. Mudiyanse RM. Thalassemia treatment and prevention in Uva Province, Sri Lanka: A public opinion survey. Hemoglobin 2006;30(2):275-89.

17. Delea TE, Edelsberg J, Sofrygin O, et al. Consequences and costs of noncompliance with iron chelation therapy in patients with transfusion-dependent thalassemia: A literature review. Transfusion 2007 Oct;47(10):1919-29.

18. Riaz H, Riaz T, Khan MU, et al. Serum ferritin levels, socio-demographic factors and desferrioxamine therapy in multi-transfused thalassemia major 
patients at a government tertiary care hospital of Karachi, Pakistan. BMC Res Notes 2011 Aug 11;4:287.

19. Eissa DS, El-Gamal RA. Iron overload in transfusiondependent B-thalassemia patients: Defining parameters of comorbidities. Egyptian journal of haematology 2014;39(3):164-70.

20. Mishra AK, Tiwari A. Iron overload in beta thalassaemia major and intermedia patients. Maedica (Buchar) 2013 Sep;8(4):328-32.

21. Suzuki T. Iron overload and iron chelation therapy in transfusion-dependent patients. [Article in Japanese]. Nihon Rinsho 2008 Mar;66(3):563-8.

22. Ceci A, Mangiarini L, Felisi M, et al. The management of iron chelation therapy: Preliminary data from a national registry of thalassaemic patients. Anemia 2011;2011:435683.

23. Belhoul KM, Bakir ML, Kadhim AM, Dewedar HE, Eldin MS, Alkhaja FA. Prevalence of iron overload complications among patients with $\beta$-thalassemia major treated at Dubai thalassemia centre. Ann Saudi Med 2013 Jan-Feb;33(1):18-21.

24. Brittenham GM, Cohen AR, McLaren CE, et al. Hepatic iron stores and plasma ferritin concentration in patients with sickle cell anemia and thalassemia major. Am J Hematol 1993 Jan;42(1):81-5.

25. Hashemi A, Ghilian R, Golestan M, et al. The study of growth in thalassemic patients and its correlation with serum ferritin level. Iranian Journal of Pediatric Hematology Oncology 2011;1(4):147-51.

26. Saka N, Sükür M, Bundak R, Anak S, Neyzi O, Gedikoglu G. Growth and puberty in thalassemia major. J Pediatr Endocrinol Metab 1995 JulSep;8(3):181-6.

27. Pitteloud N. Managing delayed or altered puberty in boys. BMJ 2012 Dec 3;345:e7913.

28. Sex steroid treatment for pubertal induction and replacement in the adolescent girl: Royal college of obstetricians and gynaecologists - scientific impact paper. 2013.

29. World Health Organization. Multicentre growth reference study group. WHO child growth standards: Length/height-for-age, weight-for-age, weight-forlength, weight-for-height and body mass index-forage: Methods and development. 2006:312.

30. Hows J, Hussein S, Hoffbrand AV, Wickramasinghe SN. Red cell indices and serum ferritin levels in children. J Clin Pathol 1977 Feb;30(2):181-3.

31. Shah N, Mishra A, Chauhan D, Vora C, Shah NR. Study on effectiveness of transfusion program in thalassemia major patients receiving multiple blood transfusions at a transfusion centre in Western India. Asian J Transfus Sci 2010 Jul;4(2):94-8.

32. Lucas GN, Perera BJ, Fonseka EA, De Silva DD, Fernandopulle M. A trial of deferiprone in transfusiondependent iron overloaded children. Ceylon Med J 2000 Jun;45(2):71-4.

33. Choudhry VP, Pati HP, Saxena A, Malaviya AN. Deferiprone, efficacy and safety. Indian $J$ Pediatr 2004 Mar;71(3):213-6.

34. Al Jaouni SK. Survival and disease complication of thalassemia major: Experience of 14 years at king Abdulaziz Universityn Hospital, Jeddah. JKAU Med Sci 2010;17(1):19-28.

35. Cunningham MJ, Macklin EA, Neufeld EJ, Cohen AR; Thalassemia clinical research network. Complications of beta-thalassemia major in North America. Blood 2004 Jul 1;104(1):34-9.

36. Eghbali A, Taherahmadi H, Shahbazi M, Bagheri B, Ebrahimi L. Association between serum ferritin level, cardiac and hepatic T2-star MRI in patients with major $\beta$-thalassemia. Iran J Ped Hematol Oncol 2014;4(1):17-21.

37. Soliman AT, elZalabany M, Amer M, Ansari BM. Growth and pubertal development in transfusiondependent children and adolescents with thalassaemia major and sickle cell disease: A comparative study. J Trop Pediatr 1999 Feb;45(1):23-30.

38. Gomber S, Dewan P. Physical growth patterns and dental caries in thalassemia. Indian Pediatr 2006 Dec;43(12):1064-9.

39. Olivieri NF, Koren G, Harris J, et al. Growth failure and bony changes induced by deferoxamine. Am J Pediatr Hematol Oncol 1992 Spring;14(1):48-56.

40. Grundy RG, Woods KA, Savage MO, Evans JP. Relationship of endocrinopathy to iron chelation status in young patients with thalassaemia major. Arch Dis Child 1994 Aug;71(2):128-32.

\section{SUGGESTED READING}

- Galanello R, Origa R. Beta-Thalassemia. Orphanet Journal of Rare Diseases 2010; 5:11.

- $\quad$ Olivieri NF. The $\beta$-Thalassemias. N Engl J Med 1999; 341(2): 99-109.

- $\quad$ Rund D, Rachmilewitz E. $\beta$-Thalassemia. N Engl J Med 2005; 353:1135-46. 
Access full text article on other devices

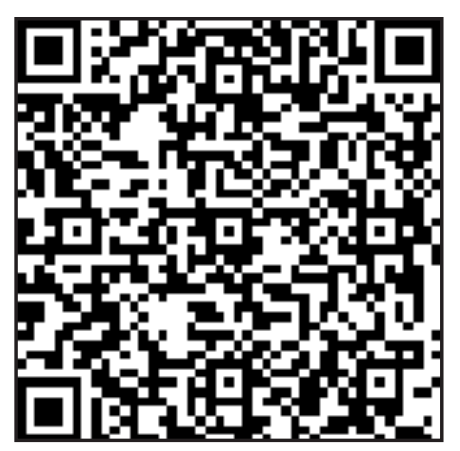

Access PDF of article on other devices

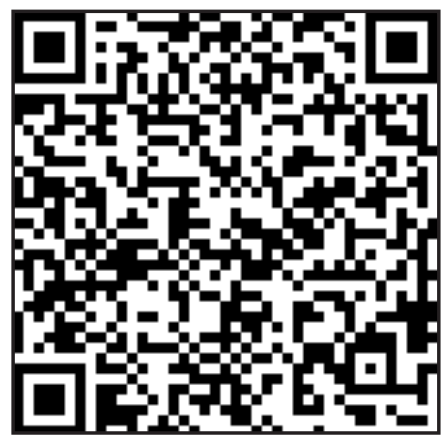

